\title{
Introduction
}

\section{Ethics in World Politics: Cosmopolitanism and Beyond?}

\author{
James Brassett ${ }^{\mathrm{a}}$ and Dan Bulley ${ }^{\mathrm{b}}$ \\ ${ }^{a}$ Centre for the Study of Globalisation and Regionalisation, University of Warwick, \\ Coventry CV47AL, UK. \\ E-mail: jamesbrassett@yahoo.com \\ ${ }^{b}$ Department of Politics and International Studies, University of Warwick, Coventry \\ CV47AL, UK. \\ E-mail: d.j.bulley@warwick.ac.uk
}

International Politics (2007) 44, 1-18. doi:10.1057/palgrave.ip.8800155

The study of world politics now comprises a broad range of disciplinary and theoretical perspectives. ${ }^{1}$ Such breadth holds important implications for understanding ethics and 'the ethical' in world politics. Where once International Relations (IR) claimed a monopoly over the study of world affairs, there is now a plurality of capable observers from disciplines like Geography, International Political Economy, and Sociology. Where once the dominant paradigms of IR succeeded in the effective exclusion of 'the ethical' from world politics - either by asserting a difference between domestic order and international anarchy, thus deferring questions of ethics until international community is achieved (Ashley, 1987); or by treating ethics as a potential 'doctor' for IR, a body of principles that can be imported from outside, once they are finally agreed (Walker, 1993: 50) - there is now a growing reflection on the limits of such thinking by critical, feminist and post-structural scholars.

For such theorists ethics is always-already political. Rather than a simple set of principles which can be applied to this or that 'case,' questions of 'the ethical' are intertwined with the doubt and contestability of politics. As Thomas Keenan observes, 'We have politics because we have no grounds, no reliable standpoints - in other words, responsibility and rights, the answers and the claims we make as foundations disintegrate, are constitutive of politics' (Keenan, 1997: 3). Importantly, there can be no easy resolution (salvation?) in ethics, merely uneasiness in one's own position and a responsibility to consider and converse (Brassett and Merke, 2005). With these assumptions in mind the contributors to this Special Issue were invited to a workshop at the University of Warwick to examine the way questions of the 'ethical' are framed in the study of world politics.

In the academic and policy communities, increased attention is given to cosmopolitanism as a normative framework for addressing world politics. 
Against the backdrop of globalization, cosmopolitanism has become a key reform agenda that seeks to humanise aspects of what might be loosely termed global public policy (Held, 1995). At the same time post-structural and critical perspectives challenge traditional cosmopolitan assumptions (Patomaki, 2003; Walker, 2003). For such theorists, the cosmopolitan belief that the vagaries of world politics can be confronted and overcome via correct deployment of reason and international law contains 'effective silences' that enact a violence towards alternative possible futures. However, such differences notwithstanding, certain common questions may be addressed:

Is 'the state' any longer a useful 'space' to talk of justice and morality? What status do ethical 'principles' have in the study and practice of world politics? How can we make judgements about the ethics of states, markets, and individuals in situations of war, intervention and capital mobility? What 'silences' are enacted in current discourses surrounding the 'War on Terror'? How are 'human rights' produced and affirmed, and what implications does this have? And in a period of bullish US supremacy what is the normative status of international laws and norms that might prevent from instability and aggression?

The aim of drawing this (broad) remit is to continue a conversation on ethics that is sometimes deferred in favour of theoretical or disciplinary isolation. Such a conversation should remain open and unrestricted. A synthesis of positions is unlikely and, more importantly, undesirable; rather different critical approaches can reveal different problems and inconsistencies in the way 'the ethical' is framed. One 'Ethics' of world politics is not the goal. Rather, by acknowledging the always-already political nature of ethics, we see the opening of a transdisciplinary and critical space as an important move per se. Juxtaposing cosmopolitanism with different critical perspectives can force cosmopolitans to get their 'feet dirty' by confronting the ethical limits of their work. ${ }^{2}$ Likewise, by inviting critical theorists to engage these debates, they are able to articulate the implications of their arguments to a different audience and put into practice an oft-stated belief in methodological pluralism (e.g. Der Derian, 1997: 55).

The Introduction will review each of the contributions and suggest some possibilities for moving beyond cosmopolitanism. We accept that this move is not self-evident. As Robert Fine remarked at the workshop, 'It seems like only yesterday that cosmopolitanism was the beyond!' But what we are suggesting is slightly different. In the engagement between cosmopolitan and critical perspectives there may be opportunities to move beyond the traditional assumptions and dilemmas found in debates about ethics in world politics. Previous conceptions of normative theory $v s$ political reality, or of cosmopolitan vs communitarian, are not considered as the prime questions here. In pragmatic fashion, 'the beyond' may be less pretentiously described as 
a different set of questions, or perhaps another way of addressing old questions. We therefore frame the beyond as a conversation, not a destination.

To this end, we argue that it would be a mistake to set-up another totalizing dichotomy: cosmopolitan vs post-structural. At one level this would ignore the plurality of approaches that prosper within each broad heading. As the sections of this Introduction argue, the 'beyond' of cosmopolitanism is now being worked on by writers in both the cosmopolitan and post-structural 'camps' who seek to embed ethics in politically contingent and contestable 'reality'. At another level, we suggest a different way to regard a subject of this conversation. Dropping epistemological differences for a moment, it is argued that a possible common ground could exist for ethical theorists, namely: suffering.

If we consider a key contribution of ethics and ethical reflection as the steady expansion of the scope of what counts as meaningful suffering, then new possibilities can be suggested. On this understanding, it can be argued that cosmopolitans do a good job of highlighting our vulnerability to social discrimination, poverty, and violence in global perspective. If post-structural approaches add to this list the notion that 'the unproblematic adoption of ethical frameworks is itself a medium that produces suffering' — via categories like territory, citizenship, and 'ethics' - then this is an important contribution to the conversation. It is not a conversation stopper as some suppose. To continue it, cosmopolitan attempts to mitigate 'suffering' should apply the caveat: 'where the concept of suffering restricts from final definition'. And the post-structural concern with 'ontological vulnerability' will help to keep ethical theorists acutely aware of potential forms of suffering. Building in such theoretical responsibility may seem an overly scholastic exercise but, as the concluding section argues, it holds important implications for the praxis of ethics in world politics.

\section{Cosmopolitan Ethics in World Politics}

Cosmopolitan thinking can claim a long and venerable lineage in (western) political theory that runs through Greek philosophy, Christian theology, Kantian critical theory and liberalism (See Smith and Vaughan-Williams in this Issue). In recent decades and due to the work of a few key scholars cosmopolitan thinking has undergone a revival across the social sciences. Emboldened by the end of the Cold War and (partly funded by) a newfound zeal within international institutions like the UN, cosmopolitan thought has now achieved the status of an '-ism' (Fine, 2003). This subtle grammatical change has telling implications for the discussion of cosmopolitan ethics in world politics. On the one hand, the political nature of cosmopolitan thought is 
consolidated by its shift to an ideological, or at least, paradigmatic status. Reflexively, a key reason for looking at cosmopolitanism over other equally important traditions is a recognition that cosmopolitan agendas and authors are in a golden period of productivity and influence. On the other hand, the broadening of the term has created a problem of caricature. As Booth, Dunne and Cox (2001) argue:

Defenders of such thinking have sometimes had their work labelled 'Kantian', which for some critics implies the embracing of an out of date package of Enlightenment outlooks (with all this implies for their views about international politics, including an untenable universalism) (2001, p. 7).

Such caricature has often led critics to miss the often diverse and nuanced positions that fall under the broad rubric of cosmopolitanism. And to the extent that the papers presented here depart from the caricature they must all be considered in some sense beyond. So it is perhaps better to think about cosmopolitans as inspired by certain ideas. These ideas are those of the avoidance of unnecessary suffering because of war or poverty, and the possibility of building institutions that can allow for the realization of freedom.

An interesting point is that such ideas can lead to remarkably different projects. Indeed, in his contribution, 'Anticipating a Cosmopolitan Future: The Case of Humanitarian Military Intervention,' Will Smith identifies a striking divergence between cosmopolitans over the issue of humanitarian intervention by military means. While some authors have taken widespread abuses of human rights as a clear justification for the use of military intervention in 'this world', Daniele Archibugi (2003: 268) is against it; unable to condone 'humanitarian violence' until suitable cosmopolitan legal and institutional reforms have been achieved. However, against the latter position, Smith suggests:

It seems counterintuitive to effectively postpone the possibility of military responses to these crises until the arrival of a cosmopolitan world, where there may, for all we know, be less need for military interventions. The challenge for cosmopolitans is how to orient themselves in a world where serious humanitarian crimes occur but where few effective means are available to respond to them.

Smith thus pursues a careful critique of cosmopolitan thinking as it is actively applied to humanitarian intervention. He focuses on how one particular cosmopolitan, Jurgen Habermas, has articulated his thought in the context of specific military interventions in Kosovo and Iraq. By moving to context Smith is able to draw out an important point that is often missed by the more ardent critics of cosmopolitanism: its sensitivity to context. He shows how in the 
consideration of military intervention, Habermas uses his belief in cosmopolitan principals as regulative ideals. Such regulative ideals inform but do not dictate the contours of a response to intervention, by addressing the context of each decision. Indeed, for Smith, a critical analysis of this faculty leads to a question of whether 'perhaps in complex non-ideal conditions, general principles can not play a decisive role in guiding judgements about the use of force?'

The importance and difficulty of cosmopolitan judgement is a crucial element in the cosmopolitan paradigm that is sometimes overlooked by critics and supporters alike. The judgement faculty that Smith identifies between regulative ideals and the specific context of political decision points to an interesting dichotomy between the ideal and the real. On the one hand, scholars like David Held and Andrew Linklater seek to identify the evolution of a specific form of rationality in human society, charting the way in which reason can foster inclusion and reduce exclusion. On the other hand, such writers are often quite able to move from the role of dispassionate observer to a position of political advocacy. In one of the discussions at the workshop, Andrew Linklater listed the 'political effectiveness' of the concept of citizenship as a means to emancipate previously marginalized peoples. Similarly, in a past debate with Barry Buzan, David Held (1998) contended:

...the contemporary world is one in which we need to re-invent the idea of democracy - not surrender it. The project of cosmopolitan democracy involving the deepening of democracy within nation-states and extending it across political borders - is neither optimistic nor pessimistic with respect to these developments. It is a position of advocacy (1998: 394).

The use of terms like 'political effectiveness' and 'advocacy' infers a step into a world which is far less certain, far more contingent, and perhaps far more open to scrutiny than the dry world of philosophical reflection about ideal conditions. To put the point bluntly, it is one thing to identify that Kant is universalistic on certain points, or, that cosmopolitanism is Eurocentric (though these critiques repay consideration). However, it is quite another proposition to engage with a cosmopolitanism that is self-consciously political and therefore more able to reflect on the precariousness of its own moral judgement. Indeed, as Smith concludes in his piece, while there may be weaknesses with Habermas' interventions on intervention,

particularly his tendency to overstate the sense in which Continental European powers and the Kosovo intervention promoted the ideal of a cosmopolitan legal order [...] It is in and through the judgements of politically engaged sympathisers like Habermas that cosmopolitanism 
appears not just as a distant and somewhat abstract political ideal, but as an embedded way of thinking about the world...

The notion of embedding cosmopolitanism in current practices is taken up by Andrew Linklater in his defence of cosmopolitan obligations to distant suffering. In a context of mounting criticism of the cosmopolitan project on grounds that it is not neutral between different moral codes and contains the seeds of new forms of power and domination' Linklater explores the contours of an 'embodied cosmopolitanism'. Such a model is not a blueprint for world government, nor is it lost in philosophical abstraction. Rather it is grounded reflection on the capacity and likely avenues for increasing sensitivities to, and sympathy for, human suffering. Such 'cosmopolitan emotions', he argues, can foster both the kind of charitable responses to natural disaster witnessed after the Tsunami and Hurricane Katrina, and the possibility to foster more long-term transformations of the global system posited by writers like Thomas Pogge (2002).

Linklater is keen to make the move from 'charity' to 'duty' in the construction of cosmopolitan ethics. By charting a nuanced line between negative duties not to harm and the way positive duties to alleviate suffering are socially constructed, Linklater's contribution places human vulnerability at the heart of cosmopolitan ethics. His point is that the most basic 'human vulnerabilities are much the same everywhere' and that '[a] sense of responsibility for endangering these universal pre-requisites can be developed from emotional dispositions regarding harm to others...' These dispositions do not need to be invented; they are common to most societies. And for Linklater, ' $[\mathrm{t}]$ his emphasis on the immanence of universal obligation in everyday realities is the key to embodied cosmopolitanism.' Such a view is obviously political in its desire to engage immanent social possibilities. And it also speaks to what could be understood as a core theme of ethics and the ethical: how do we understand and mitigate suffering?

For Linklater, the question is answered by expanding the scope of ethical concern via the anticipation of immanent trends in social relations. In this way he highlights the social basis of ethics - for so long a bulwark of the cosmopolitan-communitarian debate. However, by looking to practice in this way Linklater implies that the cosmopolitan-communitarian divide is in fact far less rigid than may be supposed. Situated or embedded cosmopolitans understand and actively theorize community-related issues. Indeed, when it comes to concrete political engagement it is arguable that the two 'sides' often share far more in practical terms than this dichotomous framing would suggest (see Parker and Brassett, 2005).

This possibility of crossing the divide is explored more explicitly by Toni Erskine, in her contribution entitled: 'Qualifying Cosmopolitanism: Solidarity, 
Criticism, and Michael Walzer's 'View from the Cave'. Accepting that cosmopolitanism must face significant charges — including a neglect of local culture by adopting a spurious objectivity — the question that motivates Erskine is "whether it is conceivable to somehow qualify the standard ethical cosmopolitan perspective so that it allays the apprehensions of its critics and sceptics - without forfeiting its claim to an inclusive and critical moral purview.' To do this, she turns to the concept of embedded cosmopolitanism and asks how the work of Michael Walzer can help to situate ethics.

Michael Walzer is one of the most significant of the so-called communitarian philosophers and by engaging with the broad scope of his work Erskine takes discussion beyond the common IR framing of Walzer as just a just war theorist. Erskine makes a critical review of Walzer's body of work in terms of his attempt to mediate between a 'radically particularist' (Walzer, 1983, xiv) starting point for morality and certain minimal universal codes. Walzer's various proposals for mediating between the universal and the particular have included the idea of 'connected criticism' — where a thin universal morality can serve as background forum for debates and discussion between thicker communities — and 'empathetic attachment' — which allows for a thin solidarity to evolve due to sentimental identification. However, Erskine argues that any attempt to step outside of the particularity of community must impose some form of impartiality, thus contradicting the project. This problem is not so much an issue of coherent argument, as a foundational question of how the particular community is defined. She is especially concerned that Walzer all too easily falls back on a spatial and often state-centric ontology.

For Erskine, an embedded cosmopolitan project can be salvaged via re-thinking the social ontology of ethics: 'One way of approaching such a redescription is to envisage the community in a way that is not necessarily spatially defined like Walzer's 'cave'.' Erskine looks to the work of feminists who reflect on the experience of what Marilyn Friedman calls 'dislocated communities' and proposes that 'the communities that define us are best understood as multiple, multifarious, overlapping, and often territorially dispersed [...] A web of intersecting and overlapping morally relevant ties with the moral agent radically situated in the centre — seems a more appropriate image of these communities than the model of separate caves.' By adopting this image:

One is not limited to a process of exposing contradictions in the espoused norms and practices of a single, bounded community. Instead, there is a possibility of revealing internal tensions across the multiplicity of communities to which one belongs. Indeed, this very multiplicity (where it exists) 
will militate against the acceptance of norms that advocate exclusion and enmity towards those outside any one community.

In this way, Erskine echoes Smith and Linklater by envisaging a form of embedded ethics that attempts to work within existing social realities. The approach is suitably qualified in terms of outcome and seeks to think through the important ontological foundations of 'where we start from'. Smith locates in the context of one cosmopolitan judging. Linklater is concerned by the possibility of immanent trends toward sympathy for suffering in multiple contexts. And Erskine asks the question of what is the appropriate conception of community for embedding cosmopolitan ethics. To the extent that they eschew any crude universality they all take us beyond the caricature of cosmopolitanism. However, as the next section will argue, this move may suffer from undue optimism regarding the possibility of 'knowing' the reality we seek to embed within.

\section{Post-Ethics in World Politics?}

While our discussion of Smith, Linklater and Erskine can be problematically contained under the simple subtitle of 'Cosmopolitan Ethics in World Politics', this analytical fiat is harder for the more 'critical' approaches. Under this rubric, we mean those scholars who are often given a post-prefix (poststructural, post-modern, post-positivist etc.) for eschewing universal moral foundations. Such theorists are sometimes regarded as ineligible for ethical discussion. As James Der Derian (1997: 55) comments, 'there has been in IR a disposition to take the path of least intellectual resistance in dealing with' this subject, a tendency to 'dismiss it by polemic or ignore it through arrogance'.

Matters were not helped by the fact that certain post-structural scholars provocatively declared themselves to be against ethics (Caputo, 1993). However, this move was not made in defence of amorality or nihilism despite regular attributions to that effect. Instead, it highlighted a tendency for theorists concerned with ethics and justice to ignore the constitutive ambiguities and contradictions that pervade these very subjects. For critical, or post-structural, thinkers such ambiguities restrict or undermine the very possibility of 'ethics' (Campbell and Shapiro, 1999: x-xi). The unproblematic usage of highly complex and sometimes badly thought-through terms like 'ethics', 'cosmopolitan', and 'justice' makes such theorists feel uncomfortable. So post-structural approaches do not aim to produce a 'theory' of ethics and world politics, indeed, as David Campbell surmises:

What is urgently required is not the construction of a theory, much less a theory of international relations, or perhaps even less a theory of ethics for international relations... What is required is an ethos of political criticism that is concerned with assumptions, limits, their historical production, social 
and political effects, and the possibility of going beyond them in thought and action (Campbell, 2005: 133, see also, Campbell, 1998: 4).

Moreover, as suggested at the start of this section, neither can we really talk about 'them' as a cohesive school in the way that cosmopolitans are often presented. Cosmopolitans at least have the (mythical) common figures of Immanuel Kant and Saint Paul among others to refer to. In contrast, 'critical' thinkers refer to a diverse and sometimes contradictory range of philosophers, psychoanalysts and social theorists: Martin Heidegger, Michel Foucault, Jacques Derrida, Jean-Luc Nancy, Judith Butler, Luce Irigaray, Emmanuel Levinas, Friedrich Nietzsche, Giorgio Agamben, Carl Schmitt, Slavoj Zizek and Jacques Lacan to name but a few.

Given the diversity of this 'non-school' it is unsurprising that its 'nonmembers' have not sought to provide a sustained critique of cosmopolitanism in their contributions. For example, in his contribution Stuart Elden does not even refer to cosmopolitanism. Rather he focuses on a forensic empirical analysis of the way that the 'War on Terror' can be more productively analysed as a 'War on Territorial Integrity.' Here he is perhaps playing on what William Connolly identifies as the two derivations of 'territory'. On the one hand, 'territory' derives from the Latin terra, meaning land or soil as a form of sustenance or nourishing. On the other hand, territory also derives from terrere, meaning to terrorize and exclude, and territorium 'a place from which people are warned'. Thus, the second meaning seems to suppress the first (Connolly, 1995: xxii). A war on terrere is equally, and problematically then, a war on terra.

Elden examines how British and American foreign policies have developed in parallel and diverging ways on the question of unilateralism vs multilateralism. He highlights the way that in both cases '[t]he question of ethics is rarely far away, both as a cause and in opposition.' Ethics have regularly been used to justify contravention of the UN Charter, and in an original take on the question of such intervention, Elden suggests we examine it 'through the lens of territorial integrity'. As he identifies, the concept of territorial integrity has two meanings in international law: (1) the preservation of existing territorial boundaries, and (2) that within this territory, the state is sovereign and inviolable. The wars in Kosovo, Afghanistan and Iraq were all partly justified by the desire of Blair, and then Bush and Blair, to preserve the territorial integrity of each state. And in each of these cases, but especially in the focus on Iraq, it is noted, '[j] ust as [their] territorial sovereignty was being violated, the preservation of [their] existing territorial settlement was a priority. Thus, territorial integrity has become a concept divided against itself.' Like the concept of territory (both as terra and terrere) and even ethics, one aspect must be silenced to justify the other; it must be violated in order to be preserved. 
In a direct contrast to Elden's paper, Zehfuss suggests immediately that 'arguments for the war cannot effectively be contested logically; rather we must highlight the way in which they produce what they name.' A common theme among more critical approaches is to thus ask different questions. Ashley suggests that if we ask 'where' and 'what' questions (e.g. where is the border, and what is the border?), we are assuming the unproblematic pre-existence of the thing in question (the border). If, instead, we ask 'how' questions (e.g. how was the border constructed?), we reveal the historicity and contingency of it (the border) and how its appearance as 'natural' orders discourse and stifles debate (Ashley, 1989: 311). In a similar vein, Roxanne Lynn Doty points out that in analysing foreign policy, asking 'why' a decision was taken and whether it was justified means we 'presuppose a particular subjectivity ... a background of social/discursive practices and meanings which make possible the practices as well as the social actors themselves.' Instead, Doty asks 'how-possible' questions, such as, how was it made possible that this was seen as the only course of action? In this way, she can analyse how the problem, its subjectivities and their relationships, were constructed to produce a certain answer (Doty, 1993: 279-299).

Zehfuss observes that contesting the justifications for war on simplistic logical grounds must be resisted. 'In order to intervene critically... we must challenge the question and highlight the ethico-political decisions that have already gone into - and that are at the same time concealed by - posing it.' Indeed, referring back to Smith's contribution it might be interesting to consider that judgements about whether we should have gone to war with Iraq - including Habermas' cosmopolitan judgements — do not question the very 'we' contained in that sentence; in this way they reproduce and fail to question the rhetoric of Blair and Bush which asks 'us' to stand up for what 'we' know is right. Using the work of Judith Butler, Zehfuss contends that the 'we' is only produced socially, in the encounter with others - the 'them'. Speaking ethically then demands a violence towards the other and towards ourselves: 'it relies not only on an impossible delineation of "us" and "them", but also suggests the independent and prior existence of both'.

This impossibility of knowing who we actually are, before we act and produce our 'selves', means that we are radically vulnerable, to others as well as ourselves. Thus while Zehfuss does not set out to critique (or even mention) cosmopolitanism, her conception of vulnerability undermines certain elements of Linklater's 'embodied cosmopolitanism'. We are vulnerable not only in the sense Linklater raises - 'to basic forms of mental and physical suffering' but in the very fact that 'we' are dependent upon others to even know who 'we' are. Our subjectivity, our ipseity, our self, our very possibility of saying 'our', is therefore radically vulnerable to the others on whom it depends. Being is always a being-with (Edkins, 2005: 379-380). 
Elden and Zehfuss can both be seen to question on very different levels the ethics of the ethical in world politics. But this question becomes even more problematic when, as Walker observes, ethics and international relations are commonly seen as an 'intersection' where a set of unproblematic rules and principles are simply applied to an anarchic realm in need of moral guidance (Walker, 1993: 50). In her contribution, Kimberly Hutchings notes this tendency in the very title of this special issue. The separation of 'world politics' and 'ethics' with the joining 'in' implies that although 'world' and 'politics' belong together, 'ethics' is something different, something that is more likely to be introduced from outside. In contrast, she seeks to show that ethics 'does not operate as a counter to world politics' but rather as 'one of the discourses through which world politics is actively produced and reproduced.' In particular, feminist perspectives on ethics in world politics are read by Hutchings as efforts to ascertain ethical values that can then be used to transform world politics and judge the legitimacy of political violence. Hutchings characterizes these feminist attempts in three categories of 'enlightenment', 'care' and 'postcolonial' feminism, showing their diverging attitudes to the use of political violence. Two of these - enlightenment and care feminism - are heavily influenced by cosmopolitan sympathies. Through this analysis Hutchings shows that there 'can be no straightforward answers to the question of what feminist ethics in world politics might mean.' There can be no moral certainty in the political judgements that are made. However, in feminists' critiques of each other they reveal the more general problem: that of seeking to apply ethics as a 'magic, external ingredient.'

Instead of feminist ethics being seen as something we apply it could fruitfully be seen as something that produces world politics itself. Ethics is always already in world politics, producing it and being produced. Hutchings demonstrates this by the way gender is used to construct the archetypal portrayal of citizens as women and soldiers as men to justify political violence as potentially unethical (on women/citizens) or ethical (on men/soldiers). Gender thus provides 'a kind of ethical shorthand which helps to render certain kinds of positions of violence intelligible.' This gendering of the ethical debate was very much in evidence when former Foreign Office Minister, now Solicitor General, Mike O'Brien explained the role ethics played in the decision to go to war in Kosovo. O'Brien uses the analogy of domestic violence, saying that you should intervene when 'you hear your neighbour beat up his wife every night.' The way the ethical debate is framed is that an aggressive male (Serbia) is violently attacking a submissive, weak and defenceless female (Kosovo). Feminists therefore need to be sensitive to the way gender structures the way we view ethical-world-politics. Rather than simply applying ethical principles to world politics, Hutchings argues that ethical theorists must negotiate them. In short, gender and ethics produce that world. 


\section{Beyond Cosmopolitanism?}

The papers discussed so far have either looked at aspects of cosmopolitanism or sought to critique silences and ambiguities in the discourse of ethics in world politics. While there are obvious and interesting lines of contact between their arguments - cosmopolitans look to expand the scope of ethical concern by seeking ways to reduce suffering, and critical scholars are concerned at how the category assumptions of ethics produce the ethical limits of the 'problem' to be solved - there is one final paper that explicitly engages with the subtitle of the Special Issue. In his contribution 'Beyond a Cosmopolitan Ideal: the Politics of Singularity', Nick Vaughan-Williams critiques the limits of the dominant framing of ethics in world politics, as either polis or cosmo-polis, and seeks to demonstrate the attractiveness of new ethical imaginaries, chiefly in the concept of singularity. The importance of this argument is that it proffers a new constellation of ethical reflection. Such affirmation is sometimes thought to be anathema to post-structuralism.

Vaughan-Williams begins his critique from Rob Walker's observation (2003: 68) that cosmopolitanism should be read as a constitutive aspect of many of the problems it seeks to address. After a brief history of what he calls the 'cosmopolitan ideal' Vaughan-Williams draws out three points of weakness with it. Firstly, he outlines the problems of an implicit, and often explicit, teleology in cosmopolitan thought posing a linear progression from polis to cosmopolis. Secondly, he critiques the Euro-centricity of the cosmopolitan ideal, whose 'narrative of the unfolding of nature leading to the victory of reason that in turn leads to the emergence of a society of nations cannot be read outside the context of modernity and European colonialism'. Even in David Held's more sophisticated articulations of the cosmopolitan paradigm, he argues, there lies '.... a logic of progress where non-Europeans continually trail behind'. Thirdly, and perhaps most devastatingly for the dominant frame of ethics in world politics, Vaughan-Williams draws on the work of Jacques Derrida to demonstrate the way that cosmopolitanism re-produces a statecentric political narrative.

Taking the example of cosmopolitan hospitality towards foreigners - a key tenet of many attempts to increase the scope of ethical concern - he argues, that this hospitality is always-already limited, conditional upon and policed by the laws of the state. While hospitality would at first sight appear to increase the rights of a 'citizen of the world' over and above the state, in fact, the limited hospitality of the 'cosmopolitan ideal' simply reprises the centrality of the state in our thinking of the ethics in world politics. Cosmopolitanism actively produces the ethico-political problems it apparently seeks to resolve. Although Held recognizes and responds to these problems through increasing universal hospitality in a context of global cosmopolitical governance, the state still 
remains at the heart of his ideal. And '[t]his is problematic since it is precisely the state that produces the foreigner, immigrant, exiled, deported, or stateless person in need of greater levels of hospitality in the first place.' For example, Peter Nyers (1999: 4) explores how these terms act in practice as 'limit concepts'. By that he means 'a concept, which expresses the limits of a certain logic of intelligibility, in this case, the "political"". He emphasizes how, "limits are also foundational, as they serve as a condition of possibility for making distinctions such as inside/outside, self/other, friend/enemy, citizen/refugee and so forth.'

Such arguments show how cosmopolitanism, as the dominant way of thinking about ethics in contemporary world politics falls back into, and reproduces, the stale dichotomy of polis vs. cosmopolis. To go beyond this dichotomy, Vaughan-Williams proffers a 'relational view of subjectivity'. He follows Derrida and Nancy in a re-thinking of the subject of the ethico-political beyond the violence of state, citizen and 'human being' to the 'incalculable singularity of everyone before any 'subject". On this view, every one, and indeed every thing, is at the same time a singularity — a 'one', a 'thing' — and plural - part of an 'every', a general. As Nancy (2000: 32) has it, '[t]he singular is primarily each one and, therefore, also with and among all the others. The singular is a plural' (Nancy, 2000: 32). And as we noted with Zehfuss' paper, being is always a being-with. In this way, world politics is reconfigured, the questions change. Where traditional ethics searches for reasons that others should respond to suffering, as Edkins has it, '[w]hat becomes surprising and in need of explanation instead is why sometimes people see others' suffering as none of their business' (Edkins, 2003: 256).

A clear contrast between the 'limit' of the cosmopolitan ideal and the 'politics of singularity' can be seen in their attitudes towards institutionalization and future action. Whereas Held (1995; 1997) proposes programmed reforms to the UN and far reaching long term entrenchment of cosmopolitan institutions, Vaughan-Williams thinks the politics of singularity through the Derridean concept of democracy to come. This idea does not seek to re-construct democracy in the spatial and future oriented terms that Held employs. Instead it plays off a central paradox in the concept of Democracy itself:

On the one hand democracy respects the citizen or political subject as an absolute singularity, in other words a singular to be counted. On the other hand, there is no democracy without calculated majorities, which necessarily efface the singularity of the countable.

However, for Derrida it is precisely the impossibility of resolving this tension that allows us to contest and improve. Far from an end-point, an ethical horizon for world politics, 'the concept of a democracy to come implies a duty 
to act without delay, in keeping with the possibility of endless contestation and perfectibility already inscribed in the concept of democracy'.

For Vaughan-Williams the beyond of cosmopolitanism, must always remain potential. 'It' is the striving for the 'sheer impossibility of completely grasping singularity, given its characteristic groundlessness and uncertainty.' This call is neither removed nor amoral. On the contrary, Vaughan-Williams asserts: 'Such an approach resembles something like an everyday revolution.' While it may be possible to criticize the abstract, complex nature of such thinking, it is also important to reflect on why it is necessary. As Hutchings observes in her paper, all ethical thinkers should note that the way they conceive ethics produces world politics itself. Thus, our conception of ethics in world politics is inevitably tied up with those concepts and methods that form the dominant discourse: cosmopolitanism. To think beyond this involves thinking differently, literally using different language and thus producing a different world politics. Vaughan-Williams fascinating attempt to think a beyond should be conceived in those terms: not as a dialectical resolution of the debate, a new and triumphant ethics, but rather as a glimpse of the diversity that could be our ethico-political thinking.

\section{Conclusion: Ethics as Conversation}

Drawing the ideas contained within this Special Issue together, there are some common themes useful for understanding ethics in world politics in general and the relationship between each approach in particular. Ethics is presented as profoundly political. Whether it is in terms of what might be called the programmatic elements of cosmopolitans, who ask questions like: 'How do we change the world to limit suffering?' and 'What do we avoid?' Or in terms of the anti-programmatic, deconstructive critical papers that ask questions like 'How is the 'ethical' constructed such that certain questions are avoided, certain issues effaced?' and 'If being is always being-with are there 'better' or 'worse' ways to be-with?' The notion of power, contest, precariousness as well as the recognition that decisions (however tenuous) are being made highlight that ethics in world politics is better expressed as liminal; not linked by joining words such as 'in' or 'and', but always-already bordering and flowing into each other: ethics/world/politics, or ethico-world-politics.

But despite these common themes, the differences are not going to be effaced by joining words together. Perhaps the clearest divergence is over the status (indeed the very possibility) of ethics and the ethical. Whereas Smith, Linklater and Erskine explore the coherence and possible extension of ethical frameworks to mitigate suffering in world politics, Elden, Zehfuss, Hutchings and Vaughan-Williams inveigh that ethical frameworks produce the world they seek 
to reform. Is this a fatal blow? Or merely a qualification that in VaughanWilliams' pithy phrase, warns 'against ethico-political intervention as if it were like pressing buttons on a machine'?

We make a cursory argument that the choice is in many ways false. But this is not because of some deep philosophical reason so much as a pragmatic recognition of the benefits of a more open and plural conversation. Simply put, it might be better, more interesting, less antagonistic, and more productive to consider that a key contribution of ethics and ethical conversation to be a steady expansion of what counts as meaningful suffering? Whereas cosmopolitans identify poverty, physical vulnerability and social discrimination as the crucial questions, post-structural authors question the ontological vulnerability that is side-stepped in such accounts. To play the two off against each other - going back and forth between conditional and unconditional may be a productive way to navigate the terrain? To qualify, this is not an argument for commensurability and we should not understate the differences at issue. In an interview with Paul Rabinow, Michel Foucault (1984: 385) expressed the central divergence of this Special Issue:

I do not appeal to any 'we' - to any of those 'we's' whose consensus, whose values, whose traditions constitute the framework for a thought and define the conditions in which it can be validated. But the problem is, precisely, to decide if it is actually suitable to place oneself within a 'we' in order to assert the principles one recognizes and the values one accepts; or if it is not rather, necessary to make the future formation of a 'we' possible, by elaborating the question.

This could indeed be a problem. Cosmopolitans who work within a framework and a tradition that counts the mitigation of human suffering as the prime moral objective, who agree with Linklater and Judith Shklar that 'cruelty is the worst thing we do', are unlikely to suddenly drop the tradition in total. Likewise, poststructuralists who see ontology — and our radical ontological vulnerability - as precisely the question of ethics, are unlikely to adopt any such (existing) frameworks. Reflexively, while the first risks a loss of validation the second simply doesn't understand what could possibly count as criteria for validation. However, to understand this divergence as a problem would be to construct yet another totalizing dichotomy: cosmopolitan vs post-structural.

If we instead pursue the kind of pluralism implied within Vaughan-Williams' 'politics of singularity' - which realises that the tension between openness and closure in existing frameworks like democracy is actually a condition of the possibility of thinking new worlds - then the choice of 'either-or' can replaced with a plural logic of both-and-and-and-and (where such lists are unlikely to end). This approach looks more attractive because it allows us to view 
cosmopolitan and post-structural approaches rather like 'attempts' (among many others) to expand the list of things that count as meaningful suffering. They become less like the final word on the matter. Indeed, as Edkins (2003: 257) suggests in a discussion of a possible opposition between humanitarian sympathy and humanitarianism: 'It is not an either/or contradiction but a question of doing both, somehow.'

A clear indication of Zehfuss' and Hutchings' papers is that ontological vulnerability to suffering is produced more or less at the point of utterance. Thus unless our plan is to give up talking 'we' had better get on with the task of not only understanding but also publicising new forms of vulnerability. This is already going on in the work of those who place their narrative deconstruction on multimedia websites and movie screens. ${ }^{4}$ In this way, sophisticated arguments can enter broader public discourse. Similarly, as Linklater identifies, such publicity tactics are also ongoing in public campaigns to end poverty - and he is entirely correct to try to connect up such campaigns with thicker arguments about duty. But a critical and open conversation would identify certain ambiguities within global justice. For instance, narratives of global justice often rest upon a construction of 'us' (rich) (usually states) and 'them' (poor) (usually states). Not only does this view impose a violent subjectivity, it also leaves unquestioned the systems of capitalist accumulation that (in part) produce poverty. Even in Pogge's sophisticated account, the universal model of capitalist accumulation is left largely in tact after global reforms have been made.

An open, plural and engaged ethical conversation is required on such issues because just as ethics produces world politics, good conversation can generate alternatives. In short, a dichotomy between cosmopolitan and post-structural approaches to ethics is unnecessary and unhelpful. The task is rather to engage across perspectives, opening up alternatives and identifying blind spots. Ethics as conversation is entirely capable of supporting and fostering the development of new and plural possibilities in the context of existing and changing frameworks. The pluralism at the heart of comfortable, salaried, academic practice is increasingly able to phrase new questions/instantiate new 'we' groups in the way Foucault envisaged. And as Elden demonstrates, it is more than savvy to the task of exposing ambiguous ethics/world/politics via straightforward logical engagement. In time cosmopolitanism may indeed fade from view. But it won't be because of any epistemological or ontological critiques rather than the arrival of a new framework that helps identify and alleviate suffering in better and more imaginative ways.

\section{Notes}

1 The authors thank Mick Cox, Richard Higgott, Jan Aart Scholte and Maja Zehfuss for their belief in this project from its earliest stages. We express our gratitude to the ESRC Centre for the 
Study of Globalization and Regionalization (CSGR), University of Warwick for generous financial support. The Department of Politics and International Studies, University of Warwick also contributed. We thank Robin Cohen, Robert Fine, Monika Heupel, Tony McGrew, Federico Merke, Heikki Patomaki, Paola Rabotti, and Nisha Shah for their help. Finally, we give special thanks to our wives for their constant love and support throughout (and sometimes despite) this project.

2 Comments by Robin Cohen at the Workshop.

3 Toni Erskine made it clear at the workshop that she did not see her work as simply 'cosmopolitan'.

4 See the excellent http://www.watsoninstitute.org/infopeace/index2.cfm.

\section{References}

Archibugi, D. (2003) 'Demos and Cosmopolis', in D. Archibugi (ed.) Debating Cosmopolitics, London: Verso.

Ashley, R. (1987) 'The geopolitics of geopolitical space: toward a critical social theory of international politics', Alternatives 12(4): 403-434.

Ashley, R. (1989) 'Living on Borderlines: Man, Poststructuralism, and War', in J. Der Derian and M.J. Shapiro (eds.) International/Intertextual Relations, Lexington, Mass: Lexington Books.

Booth, T., Dunne, T. and Cox, M. (eds.) (2001) How Might We Live? Global Ethics for a New Century, Cambridge: Cambridge University Press.

Brassett, J. and Merke, F. (2005) 'Just Deconstruction? Derrida and Global Ethics', in P. Hayden and C. Ojeili (eds.) Confronting Globalization: Humanity, Justice and the Renewal of Politics, Basingstoke: Palgrave, Macmillan.

Buzan, B. and Held, D. (1998) 'Realism vs cosmopolitanism', Review of International Studies 24(3): 387-398.

Campbell, D. (1998) 'National Deconstruction: Violence, Identity and Justice in Bosnia', Minneapolis and London: University of Minnesota Press.

Campbell, D. (2005) 'Beyond choice: the onto-politics of critique', International Relations 19(1): 127-134.

Campbell, D. and Shapiro, M.J. (1999) 'Introduction: From Ethical Theory to Ethical Relation', in D. Campbell and M.J. Shapiro (eds.) Moral Spaces: Rethinking Ethics and World Politics, Minneapolis and London: University of Minnesota Press.

Caputo, J.C. (1993) Against Ethics: Contributions to a Poetics of Obligation with Constant Reference to Deconstruction, Bloomington: Indiana University Press.

Connolly, W. (1995) The Ethos of Pluralization, Minneapolis and London: University of Minnesota Press.

Der Derian, J. (1997) 'Post-Theory: The Eternal Return of Ethics in International Relations', in M.W. Doyle and G.J. Ikenberry (eds.) New Thinking in International Relations Theory, Boulder, Colorado: Westview Press.

Doty, R.L. (1993) 'Foreign policy as social construction: a post-positivist analysis of US counterinsurgency policy in the philippines', International Studies Quarterly 37(3): 367-389.

Edkins, J. (2003) 'Humanitarianism, humanity, human', Journal of Human Rights 2(2): 253-258.

Edkins, J. (2005) 'Exposed singularity', Journal for Cultural Research 9(4): 359-386.

Fine, R. (2003) 'Taking the "Ism" out of cosmopolitanism: an essay in reconstruction', European Journal of Social Theory 6(4): 451-470.

Foucault, M. (1984) The Foucault Reader: an Introduction to Foucault's Thought, London: Penguin.

Held, D. (1995) Democracy and the Global Order: From the Modern State to Cosmopolitan Governance, Cambridge: Polity Press. 
Held, D. (1997) 'Cosmopolitan Democracy and the Global Order: A New Agenda', in J. Bohman and M. Lutz-Bachmann (eds.) Perpetual Peace: Essays on Kant's Cosmopolitan Ideal, Cambridge, MA, and London: The MIT Press.

Keenan, T. (1997) Fables of Responsibility: Aberrations and Predicaments in Ethics and Politics, Stanford: Stanford University Press.

Nancy, J.-L. (2000) Being Singular Plural, Stanford: Stanford University Press.

Nyers, P. (1999) 'Emergency or emerging identities? Refugees and transformations in world order', Millennium: Journal of International Studies 28(1): 1-26.

Patomaki, H. (2003) 'Problems of democratizing global governance: time, space and the emancipatory process', European Journal of International Relations 9(3): 347-376.

Parker, O. and Brassett, J. (2005) 'Contingent borders, ambiguous ethics: migrants in (international) political theory', International Studies Quarterly 49(2): 233-253.

Pogge, T. (2002) World Poverty and Human Rights: Cosmopolitan Responsibilities and Reforms, Cambridge: Polity.

Walker, R.B.J. (1993) Inside/Outside: International Relations as Political Theory, Cambridge: Cambridge University Press.

Walker, R.B.J. (2003) 'Polis, cosmopolis, politics', Alternatives 28(2): 267-286.

Walzer, M. (1983) Spheres of Justice: A Defence of Pluralism and Equality, Oxford: Blackwell. 